\title{
IMPLEMENTASI METODE NEURAL NETWORK BACKPROPAGATION DALAM PREDIKSI INDEKS HARGA SAHAM GABUNGAN (IHSG)
}

\section{IMPLEMENTATION OF THE NEURAL NETWORK BACKPROPAGATION METHOD IN PREDICTION OF JAKARTA COMPOSITE INDEX}

\author{
Okky Putra Barus ${ }^{*}$, Christopher Wijaya ${ }^{2}$ \\ ${ }^{1,2}$ Universitas Pelita Harapan, Jln. Iman Bonjol No 6, Medan \\ *E-mail: okky.barus@uph.edu
}

\begin{abstract}
ABSTRAK
Pada era saat ini, Investasi saham di pasar modal merupakan aset yang sangat penting bagi beberapa golongan masyarakat dan juga bagi perusahaan. Dengan adanya investasi, secara langsung maupun tidak langsung dapat memberikan dampak bagi perusahaan maupun bagi masyarakat. Penelitian ini bertujuan untuk memprediksi Indeks Harga Saham Gabungan (IHSG) dengan indeks saham: Jakarta Composite Index (JKSE). Metode yang digunakan pada penelitian ini adalah Neural Network Backpropagation. Pengumpulan dataset melalui website finance.yahoo.com dengan periode 8 Mei 2018 sampai dengan 7 Mei 2021 sebanyak 757 data. Setelah melakukan proses pengolahan data, data yang tersisa adalah 724 data. Kemudian data akan dibagi menjadi $70 \%$ data training dan $30 \%$ data testing yang akan digunakan pada proses pengolahan data. Hasil pengujian menggunakan metode Neural Newtwork Backpropagation mendapatkan hasil terbaik menggunakan Kondisi ke-10 dengan nilai Root Mean Square Error (RMSE) senilai 0.010. Kemudian akan didapatkan hasil perbandingan antara harga Close aktual dengan harga Close prediksi dengan akurasi sebesar $63.06 \%$ yang dapat membantu dalam pengambilan keputusan para investor..
\end{abstract}

Kata kunci: IHSG, Neural Network Backpropagation, Data Mining, prediksi

\begin{abstract}
In the current era, stock investment in the capital market is a very important asset for several groups of people and also for companies. With the investment, directly or indirectly can have an impact on the company and for the community. This study aims to predict the Composite Stock Price Index (JCI) with the stock index: Jakarta Composite Index (JKSE). The method used in this research is Neural Network Backpropagation. Dataset collection through the finance.yahoo.com website for the period from May 8, 2018 to May 7, 2021, totaled 757 data. After processing the data, the remaining data is 724 data. Then the data will be divided into $70 \%$ training data and $30 \%$ testing data which will be used in the data processing process. The test results using the Neural Network Backpropagation method get the best results using the 10th condition with a Root Mean Square Error (RMSE) value of 0.010. Then the results of the comparison between the actual Close price and the predicted Close price will be obtained with an accuracy of $63.06 \%$ which can assist investors in making decisions.
\end{abstract}

Keywords: JCI, Neural Network Backpropagation, Data Mining, Prediction

\section{PENDAHULUAN}

Pada era saat ini, investasi saham di pasar modal merupakan aset yang sangat penting bagi beberapa golongan masyarakat dan juga bagi perusahaan. Selain dari hak kepemilikan perusahaan dan pembagian keuntungan, pergerakan harga saham juga menjadi sumber keuntungan lain dari pergerakan harga saham. (Kompasiana, 2017). Dengan adanya investasi, secara langsung maupun tidak langsung dapat memberikan dampak bagi perusahaan. Dengan demikian saham perusahaan bukan lagi milik individu 
atau perorangan melainkan sudah dapat dimiliki oleh public atau Go Public. (Saretta, 2020)

Sedangkan bagi masyarakat ataupun investor berharap dapat mendapatkan keuntungan dalam menanamkan modalnya ke dalam pasar saham. Untuk mendapatkan keuntungan tentunya perlu dilakukannya suatu analisis untuk memprediksi arah dan harga saham.

Indonesia merupakan salah satu negara yang sangat aktif dalam investasi saham di pasar modal. Pasar modal (capital market) merupakan pasar untuk berbagai instrumen keuangan jangka panjang yang bisa diperjualbelikan, baik surat utang (obligasi), ekuiti (saham), reksadana, instrument derivatif maupun instrument lainnya. Pasar modal merupakan sarana pendanaan bagi perusahaan maupun institusi lain (misalnya pemerintah), dan sebagai sarana bagi kegiatan berinvestasi. Dengan demikian, pasar modal memfasilitasi berbagai sarana dan prasarana kegiatan jual-beli dan kegiatan terkait lainnya. (Maulana \& Kumalasari, 2019)

Harga saham di pasar modal bergerak secara acak. Ada beberapa faktor yang bisa mempengaruhi IHSG, salah satunya adalah faktor makroekonomi. Faktor makroekonomi yang berpengaruh adalah tingkat inflasi, nilai tukar rupiah, dan tingkat suku bunga sertifikat bank Indonesia. (Krisna \& Wirawati, 2013). Dalam dunia saham juga dikenal istilah Trading. Definisi Trading secara umum adalah suatu konsep dari ekonomi dasar yang di dalamnya terdapat aktivitas jual beli produk barang atau jasa. Di dalam konsep finansial, kegiatan trading ini lebih mengacu pada aktivitas jual beli sekuritas seperti saham. Selain itu, trading juga kerap kali dilakukan di pasar berjangka dan juga pasar valuta asing atau yang saat ini sering kita dengar sebagai forex (foreign exchange). (Accurate, 2021)

Pergerakan harga saham dapat tercermin dari candlestick. Candlestick terdiri dari Pembukaan (Open), Harga Tertinggi (High), Harga Terendah (Low), dan Penutupan (Close). Hasil prediksi yang akurat dan tepat sangat dibutuhkan oleh investor untuk mengambil keputusan yang tepat. Oleh karena itu, sangat diperlukannya prediksi dan analisis harga saham sehingga bermanfaat bagi investor untuk dapat melihat prospek investasi di masa yang akan datang dan sangat mempengaruhi keuntungan (gain) atau kerugian (loss).
Banyak metode yang dipakai untuk mendapatkan hasil prediksi dan ramalan yang kuat seperti Decision Tree, Neural Network, Naive Bayes, K-Nearest Neighbor, Support Vector Machine (SVM). Salah satunya adalah metode Neural Network yang meniru prinsip kerja jaringan saraf manusia. Jaringan Syaraf Tiruan (JST) merupakan suatu sistem pemrosesan informasi yang mempunyai karakteristik menyerupai Jaringan Syaraf Biologis (JSB) Jaringan Syaraf Tiruan tercipta sebagai suatu generalisasi model matematis dari pemahaman manusia (human cognition). (Solikhun, M.Saffi, \& Trisno, 2017)

Metode jaringan saraf tiruan banyak diaplikasikan pada peramalan. Bahkan salah satu penelitian terbaru jaringan saraf tiruan juga dapat diimplementasikan pada prediksi kesembuhan pasien covid-19 di Indonesia [1]. Bisnis - bisnis menggunakan peramalan untuk menentukan bagaimana mengalokasikan anggaran mereka atau merencanakan pengeluaran yang diantisipasi untuk periode waktu yang akan datang. Ini biasanya didasarkan pada permintaan yang diproyeksikan untuk barang dan jasa yang ditawarkan. (Tuovila, 2020). Selain itu sales forecasting karena memiliki kelebihan dalam mengerjakan suatu pekerjaan dasar data yang dikasih, pengenalan pola dan lebih baik dibandingkan metode-metode peramalan lainnya yang konvensional. Pada penelitian yang dilakukan oleh (Malyadi, Novawati, \& Purnama, 2017) dengan algoritma Neural Network. Hasil yang didapat dari peramalan indeks harga saham Ace Hardware diperoleh peramalan indeks harga saham tertinggi sebesar 0,9261 , harga indeks harga saham terendah sebesar 0,8039 dan indeks harga saham penutup sebesar 0,8276 . Pada penelitian yang dilakukan oleh (Novita, 2016). Hasil yang didapat dari memprediksi harga penutupan bank BCA yang terbaik adalah pelatihan dengan menggunakan fungsi PPT dengan menggunakan neuron [10 5 1], epoch 100 dan learning rate 0.4 sehingga menghasilkan RMSE terkecil 0.0626 dan MAE yaitu 0.0456 , sedangkan untuk memprediksi harga penutupan bank BRI yang terbaik adalah pelatihan dengan menggunakan fungsi PPT dengan menggunakan neuron [10 51 1], epoch 100 dan learning rate 0.4 sehingga menghasilkan RMSE terkecil yaitu 0.084 dan MAE 0.0487 .

Pada penelitian ini akan digunakan metode Neural Network Backpropagation. Dimana akan dilakukannya pengolahan dataset 
dengan metode yang dipakai untuk memprediksi indeks harga saham. Hasil dari penelitian ini berupa nilai RMSE dan prediksi perbandingan indeks harga Close prediksi dengan harga Close aktual.

\section{METODOLOGI}

Proses pengumpulan data dilakukan dengan cara mengambil dataset dari situs website finance.yahoo.com, dimana finance.yahoo.com merupakan properti media yang merupakan bagian dari jaringan Yahoo!. Situs ini menyediakan berita keuangan, data dan komentar termasuk penawaran saham, rilis pers, laporan keuangan. Hasil data yang dikumpulkan merupakan dataset yang berisikan data Indeks Harga Saham Gabungan dengan indeks saham IDX: Jakarta Composite Index (JKSE) dengan periode waktu tertentu.

Dari data-data yang sudah dikumpulkan terdapat beberapa variabel dari dataset. Penjelasan mengenai variabel yang dipakai sebagai berikut:

1.Open - variabel ini merupakan harga pembukaan suatu pasar pada saat periode tertentu.

2.Close - variabel ini merupakan harga penutupan suatu pasar pada saat periode tertentu.

3. High - variabel ini merupakan harga tertinggi yang terjadi dalam suatu periode perdagangan.

4. Low - variabel ini merupakan harga terendah yang terjadi dalam suatu periode perdagangan.

5.Volume - variabel ini merupakan jumlah asset yang telah diperdagangkan dalam periode waktu tertentu.

Tabel dataset kemudian akan melewati proses Data Repair dan Data Cleaning sebagai persiapan dataset untuk proses pengolahan data.

Pada penelitian ini akan digunakan metode Neural Network Backpropagation dimana akan disertakan beberapa data sampel yang diambil dari dataset keseluruhan yang kemudian akan dilakukan perhitungan manual secara bertahap.

Perhitungan ini bertujuan sebagai pembuktian dan mendeskripsikan perhitungan secara manual dari metode yang digunakan pada penelitian ini. Selanjutnya dataset akan diproses dengan menggunakan data training sebanyak $70 \%$ dan data testing sebanyak $30 \%$.

Proses selanjutnya akan dilakukan pengujian data dengan menggunakan metode Neural Network Backpropagation. Pada saat pengujian akan ditentukan learning rate, error epsilon, momentum, dan training cycles. Model Neural Network yang akan dipakai pada penelitian ini adalah dengan struktur 5-4-1. Proses pengujian akan dilakukan beberapa kali dengan kondisi training cycles yang berbeda. Hasil pengujian akan menghasilkan nilai Root Mean Square Error (RMSE) dengan nilai yang berbeda yang nantinya akan dipilih nilai yang paling kecil. Root Mean Square Error (RMSE) akan menjadi acuan sebagai kedekatan nilai yang nantinya akan diproses pada langkah selanjutnya untuk menghasilkan nilai perbandingan harga Close aktual dengan harga Close prediksi.

\section{HASIL DAN PEMBAHASAN PERSIAPAN DATA}

Tabel Dataset merupakan dataset yang didapatkan dari website finance.yahoo.com. Dataset yang digunakan memiliki 757 data. Pada saat persiapan data dilakukan tiga tahapan proses yaitu penentuan time frame, Data Cleaning, dan Data Repair:

1. Penentuan Time Frame: Pada finance.yahoo.com terdapat 3 time frame yang bisa digunakan untuk data historis yaitu Daily, Weekly, dan Monthly. Time frame yang digunakan dalam penelitian ini Daily.

2. Data Cleaning: Data Cleaning adalah proses pembersihan data apabila terdapat data yang tidak memiliki nilai (null) atau tidak lengkap.

3. Data Repair: Data Repair adalah proses perbaikan struktur data apabila adanya data yang akan digunakan mengalami kesalahan penulisan yang bisa berpengaruh terhadap hasil akurasi pada proses data mining. Data yang akan di repair adalah data yang terdapat pada atribut Open, High, Low, Close dan Volume, hal ini dilakukan karena data yang masuk dalam format excel penulisanya berubah. Setelah melakukan beberapa proses diatas, total jumlah dataset yang diperoleh dari sebanyak 757 buah menjadi 724 buah. Dataset yang sudah diperoleh akan diolah ditahapan selanjutnya.

\section{UJI KELAYAKAN DATA}

Pada tahapan ini akan dilakukan proses normalisasi dataset dengan tujuan untuk mengurangi dan menghilangkan redudansi data. Dengan adanya normalisasi maka membentuk data menjadi lebih fleksibel dan mudah beradaptasi sehingga dataset yang digunakan berkualitas baik. 


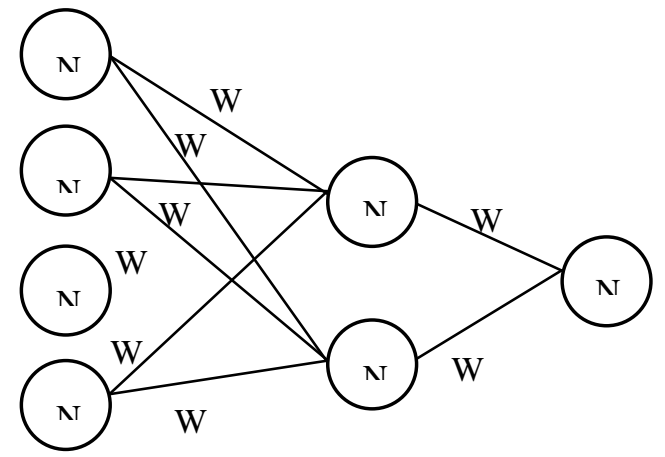

Gambar 1. Neural Network

Neural Network Gambar 1 memiliki empat node (N0,0, N0,1 N0,2 dan N0,3) pada input layer, dimana N0,0 adalah Open, N0,1 adalah High, N0,2 adalah Low dan N0,3 Volume. Dua node pada hidden layer (N1,0 dan $\mathrm{N} 1,1)$ dan satu node di lapisan keluaran $(\mathrm{N} 2,0)$ adalah Close. Node lapisan masukan terhubung ke node lapisan tersembunyi dengan bobot (W0,0-W0,7). Node lapisan tersembunyi terhubung dengan node lapisan keluaran dengan bobot (W1,0 dan W1,1). Nilai yang diberikan untuk bobot diambil secara acak dan akan diubah selama iterasi BP.

Berikut merupakan tabel pola data yang akan digunakan pada proses pengolahan data:

\begin{tabular}{|c|c|}
\hline$n 0,0$ & 0.778992 \\
\hline$n 0,1$ & 0.74 \\
\hline$n 0,2$ & 0.771736 \\
\hline$n 0,3$ & 0.29976 \\
\hline $\begin{array}{c}\text { Input } \\
n 2,0\end{array}$ & 0.76264 \\
\hline W0,0 & 0.1 \\
\hline W0,1 & 0.4 \\
\hline W0,2 & 0.2 \\
\hline W0,3 & 0.3 \\
\hline W0,4 & -0.2 \\
\hline W0,5 & 0.1 \\
\hline W0,6 & -0.3 \\
\hline W0,7 & 0.5 \\
\hline W1.0 & 0.6 \\
\hline W1.1 & -0.5 \\
\hline
\end{tabular}

$$
\begin{aligned}
& \beta=\text { Learning rate }=0.45 \\
& \alpha=\text { Momentum term }=0.8 \\
& f(x)=\frac{1.0}{\left(1.0+\exp ^{(-x)}\right)}
\end{aligned}
$$

Tampilan perhitungan untuk jaringan sederhana ini (hanya kalkulasi misalnya satu set yang akan ditampilkan (nilai input 0.778992 , $0.74,0.771736$ dan 0.29976 dengan nilai input 0.76264)). Berikut langkah-langkah tahapan penyelesaian Neural Network Backpropagation:

1. Komputasi Feed Forward

2. Backpropagation ke Lapisan Output

3. Backpropagation ke lapisan tersembunyi

4. Mempebarui Robot

Pada tahapan ini dilakukan pengujian menggunakan metode Neural Network Backpropagation. Pembagian data dilakukan sebesar 70\% untuk data training sebanyak 506 buah dan 30\% untuk data testing sebanyak 217 buah.

Pengujian data digunakan dengan menggunakan learning rate 0.02 , momentum 0.9 , error epsilon 1.0E-4 dan dengan kondisi training cycles yang berbeda di setiap perulangan pengujian yang dilakukan. Berikut merupakan hasil pengujian yang telah dilakukan:

Tabel 2. Hasil Pengujian Data

\begin{tabular}{ccccc}
\hline Kondisi & $\begin{array}{c}\text { Data } \\
\text { Training }\end{array}$ & $\begin{array}{c}\text { Data } \\
\text { Testing }\end{array}$ & $\begin{array}{c}\text { Training } \\
\text { Cycle }\end{array}$ & RMSE \\
\hline 1 & 506 & 217 & 10 & 0.016 \\
2 & 506 & 217 & 20 & 0.015 \\
3 & 506 & 217 & 30 & 0.014 \\
4 & 506 & 217 & 40 & 0.013 \\
5 & 506 & 217 & 50 & 0.012 \\
6 & 506 & 217 & 60 & 0.012 \\
7 & 506 & 217 & 70 & 0.011 \\
8 & 506 & 217 & 80 & 0.011 \\
9 & 506 & 217 & 90 & 0.011 \\
$\mathbf{1 0}$ & $\mathbf{5 0 6}$ & $\mathbf{2 1 7}$ & $\mathbf{1 0 0}$ & $\mathbf{0 . 0 1 0}$ \\
\hline
\end{tabular}

Dari Tabel 2 didapatkan nilai RMSE yang paling kecil terdapat pada Kondisi ke-10 dengan nilai 0.010 , itu menunjukan hasil nilai yang diprediksi merupakan hasil yang paling mendekati dan akurat.

Selanjutnya dilakukan pengujian dan didapatkan hasil prediksi dengan data aktual pada Indeks Harga Saham Gabungan dengan indeks saham IDX: Jakarta Composite Index (JKSE) dengan nilai RMSE 0.010. Berikut merupakan beberapa hasil pengujian yang dilakukan pada proses pengolahan data

Tabel 3 Perbandingan Harga Aktual dengan Harga Prediksi sebelum Denormalisasi

\begin{tabular}{ccc}
\hline Date & Close & Prediction Close \\
\hline May 05, 2021 & 0.780875 & 0.782183 \\
Apr 27, 2021 & 0.774635 & 0.777248 \\
Apr 19, 2021 & 0.810233 & 0.810056 \\
Apr 15, 2021 & 0.820561 & 0.807822 \\
\hline
\end{tabular}




\begin{tabular}{ccc}
\hline Apr 14, 2021 & 0.809367 & 0.796558 \\
Apr 12, 2021 & 0.770401 & 0.783108 \\
Apr 09, 2021 & 0.817002 & 0.822162 \\
Mar 31, 2021 & 0.784557 & 0.766164 \\
Mar 30, 2021 & 0.817473 & 0.81946 \\
Mar 25, 2021 & 0.83718 & 0.826068 \\
Mar 17, 2021 & 0.896313 & 0.894635 \\
Mar 05, 2021 & 0.889233 & 0.893766 \\
Mar 03, 2021 & 0.934443 & 0.925217 \\
Mar 02, 2021 & 0.92772 & 0.921547 \\
Feb 26, 2021 & 0.882739 & 0.881636 \\
Feb 24, 2021 & 0.886283 & 0.88174 \\
Feb 02, 2021 & 0.8069 & 0.819722 \\
Jan 28, 2021 & 0.782209 & 0.799785 \\
Jan 26, 2021 & 0.843804 & 0.854453 \\
Jan 06, 2021 & 0.815267 & 0.809884 \\
\hline
\end{tabular}

Hasil perbandingan harga Close aktual dengan harga Close prediksi yang sudah didapatkan, selanjutnya akan dilakukan proses denormalisasi dikarenakan dataset yang digunakan pada saat pengolahan data adalah dataset normalisasi. Berikut hasil perbandingan harga Close aktual dengan harga Close prediksi. Untuk data selengkapnya terdapat di Lampiran B: Perbandingan Harga Aktual dengan Harga Prediksi.

Tabel 4. Perbandingan Harga Aktual dengan

\begin{tabular}{ccc}
\multicolumn{3}{c}{ Harga Prediksi } \\
\hline Date & Close & $\begin{array}{c}\text { Prediction } \\
\text { Close }\end{array}$ \\
\hline May 05, 2021 & 5975.91 & 5979.32 \\
Apr 27, 2021 & 5959.62 & 5966.44 \\
Apr 19, 2021 & 6052.54 & 6052.08 \\
Apr 15, 2021 & 6079.5 & 6046.25 \\
Apr 14, 2021 & 6050.28 & 6016.85 \\
Apr 12, 2021 & 5948.57 & 5981.74 \\
Apr 09, 2021 & 6070.21 & 6083.68 \\
Mar 31, 2021 & 5985.52 & 5937.51 \\
Mar 30, 2021 & 6071.44 & 6076.63 \\
Mar 25, 2021 & 6122.88 & 6093.87 \\
Mar 17, 2021 & 6277.23 & 6272.85 \\
Mar 05, 2021 & 6258.75 & 6270.58 \\
Mar 03, 2021 & 6376.76 & 6352.68 \\
Mar 02, 2021 & 6359.21 & 6343.1 \\
Feb 26, 2021 & 6241.8 & 6238.92 \\
Feb 24, 2021 & 6251.05 & 6239.19 \\
Feb 02, 2021 & 6043.84 & 6077.31 \\
Jan 28, 2021 & 5979.39 & 6025.27 \\
\hline & & \\
\hline
\end{tabular}

\begin{tabular}{lll}
\hline Jan 26, 2021 & 6140.17 & 6167.97 \\
Jan 06, 2021 & 6065.68 & 6051.63 \\
\hline
\end{tabular}

Untuk perhitungan akurasi antara perbandingan harga Close aktual dengan harga Close prediksi akan dilakukan sebagai berikut:

Tabel 4. 9 Tabel Perhitungan Akurasi

\begin{tabular}{|c|c|c|c|c|}
\hline Date & Close & $\begin{array}{c}\text { Predicti } \\
\text { on } \\
\text { Close }\end{array}$ & $\begin{array}{c}\text { Error } \\
\text { (Close } \\
- \\
\text { Predic } \\
\text { tion } \\
\text { Close) }\end{array}$ & $\begin{array}{c}\text { Error } \\
\% \\
(\text { Error } \\
\text { /Close } \\
* \\
100 \%) \\
\end{array}$ \\
\hline $\begin{array}{c}\text { May 05, } \\
2021\end{array}$ & 5975.91 & 5979.32 & 3.41 & 0.06 \\
\hline $\begin{array}{c}\text { Apr 27, } \\
2021\end{array}$ & 5959.62 & 5966.44 & 6.82 & 0.11 \\
\hline $\begin{array}{c}\text { Apr 19, } \\
2021\end{array}$ & 6052.54 & 6052.08 & 0.46 & 0.01 \\
\hline $\begin{array}{c}\text { Apr 15 } \\
2021\end{array}$ & 6079.5 & 6046.25 & 33.3 & 0.55 \\
\hline $\begin{array}{c}\text { Apr 14, } \\
2021\end{array}$ & 6050.28 & 6016.85 & 33.4 & 0.55 \\
\hline $\begin{array}{c}\text { Apr 12, } \\
2021\end{array}$ & 5948.57 & 5981.74 & 33.2 & 0.56 \\
\hline $\begin{array}{c}\text { Apr 09, } \\
2021\end{array}$ & 6070.21 & 6083.68 & 13.5 & 0.22 \\
\hline $\begin{array}{c}\text { Mar 31, } \\
2021\end{array}$ & 5985.52 & 5937.51 & 48 & 0.8 \\
\hline $\begin{array}{c}\text { Mar 30, } \\
2021\end{array}$ & 6071.44 & 6076.63 & 5.19 & 0.09 \\
\hline $\begin{array}{c}\text { Mar 25, } \\
2021\end{array}$ & 6122.88 & 6093.87 & 29 & 0.47 \\
\hline $\begin{array}{c}\text { Mar 17, } \\
2021\end{array}$ & 6277.23 & 6272.85 & 4.38 & 0.07 \\
\hline $\begin{array}{c}\text { Mar 05, } \\
2021\end{array}$ & 6258.75 & 6270.58 & 11.8 & 0.19 \\
\hline $\begin{array}{c}\text { Mar 03, } \\
2021\end{array}$ & 6376.76 & 6352.68 & 24.1 & 0.38 \\
\hline $\begin{array}{c}\text { Mar 02, } \\
2021\end{array}$ & 6359.21 & 6343.1 & 16.1 & 0.25 \\
\hline $\begin{array}{c}\text { Feb 26, } \\
2021\end{array}$ & 6241.8 & 6238.92 & 2.88 & 0.05 \\
\hline $\begin{array}{c}\text { Feb 24, } \\
2021\end{array}$ & 6251.05 & 6239.19 & 11.9 & 0.19 \\
\hline $\begin{array}{c}\text { Feb 02, } \\
2021\end{array}$ & 6043.84 & 6077.31 & 33.5 & 0.55 \\
\hline $\begin{array}{c}\text { Jan } 28, \\
2021\end{array}$ & 5979.39 & 6025.27 & 45.9 & 0.77 \\
\hline $\begin{array}{c}\text { Jan } 26, \\
2021\end{array}$ & 6140.17 & 6167.97 & 27.8 & 0.45 \\
\hline $\begin{array}{c}\text { Jan 06, } \\
2021\end{array}$ & 6065.68 & 6051.63 & 14.1 & 0.23 \\
\hline$\cdots$ & $\cdots$ & $\cdots$ & $\cdots$ & $\cdots$ \\
\hline $\begin{array}{c}\text { May } \\
15,2018\end{array}$ & 5838.12 & 5867.12 & 29 & 0.5 \\
\hline \multicolumn{4}{|c|}{ Total Error \% } & 36.94 \\
\hline
\end{tabular}

Akurasi $=100 \%-36.94 \%=63.06 \%$

Maka Akurasi yang diperoleh antara perbandingan harga Close aktual dengan harga 
Close prediksi dengan hasil sebanyak 216 data adalah $63.06 \%$.

Dari percobaan menggunakan $70 \%$ data testing sebanyak 506 buah data dan 30\% data training sebanyak 217 buah data. Kemudian dengan pengujian data digunakan learning rate 0.02 , momentum 0.9 , error epsilon $1.0 \mathrm{E}-4$ dan juga training cycles yang berbeda pada setiap percobaan yang dilakukan.

Dari hasil pengujian menggunakan metode Neural Network Backpropagation menunjukan hasil yang paling baik yaitu Kondisi 10 dengan nilai RMSE sebesar 0.010 . Kemudian dilakukan pengujian dengan Kondisi ke-10 didapatkan perbandingan hasil Close aktual dengan hasil Close prediksi.

Dari perbandingan hasil Close aktual dengan hasil Close prediksi, selanjutnya akan dilakukan perhitungan Akurasi dengan data sebanyak 216 dan didapatkan hasil Akurasi sebesar $63.06 \%$.

\section{KESIMPULAN}

Berdasarkan penelitian yang dilakukan terhadap Indeks Harga Saham Gabungan dengan indeks saham: Jakarta Composite Index (JKSE) maka diperoleh kesimpulan bahwa:

1. Dengan menggunakan metode Neural Network Backpropagation didapatkan hasil perbandingan antara harga Close aktual dengan harga Close prediksi dengan Akurasi sebesar $63.06 \%$.

2. Pengunaan nilai learning rate yang semakin besar, maka proses training akan berjalan semakin cepat, nilai momentum bertujuan menambahkan sebagian kecil bobot dari pembaruan bobot sebelumnya, error epsilon merupakan batasan error pada saat pengoptimalan dan training cycles menentukan jumlah pelatihan yang dilakukan pada jaringan saraf.

3. Dengan menggunakan learning rate 0,02, momentum 0,9 , error epsilon 1,0E-4 dan training cycles sebesar 100 menghasilkan nilai Root Mean Square Error (RMSE) senilai 0.010 .

4. Penggunaan learning rate, momentum, error epsilon yang sama namun training cycles yang semakin besar maka hasil nilai Root Mean Square Error (RMSE) akan semakin kecil dan akurat.

5. Dari hasil pengujian menggunakan kondisi yang berbeda-beda didapatkan hasil terbaik yaitu pada Kondisi ke-10 dengan hasil Root Mean Square Error (RMSE) senilai 0.010.

\section{SARAN}

Adapun saran pada penelitian ini adalah Penggunaan metode pengujian yang berbeda seperti penggunaan metode Linear Regression, Support Vector Machine, Decision Tree, Naive Bayes. Selain itu dapat dilakukan penambahan data uji untuk meningkatkan tingkat keberhasilan. Dan dapak menggunakan objek penelitian yang berbeda untuk diterapkan dipenelitian selanjutnya.

\section{UCAPAN TERIMA KASIH}

Penulis mengucapkan terima kasih kepada Universitas Pelita Harapan yang telah mendukung penulis untuk melakukan publikasi ini sebagai luaran mata kuliah Business Intelligence \& Data Analytics.

\section{DAFTAR PUSTAKA}

[1] O. P. Barus, "PREDIKSI KESEMBUHAN PASIEN COVID-19 DI INDONESIA MELALUI TERAPI MENGGUNAKAN METODE NAÏVE BAYES," Journal ISD, vol. 6, pp. 59-66, 2021.

[2] R. Maulana and D. Kumalasari, "ANALISIS DAN PERBANDINGAN ALGORITMA DATA MINING DALAM PREDIKSI HARGA SAHAM GGRM," Jurnal Informatika Kaputama (JIK), p. 23, 2019.

[3] M. Malyadi, N. R. Novawati and R. B. Purnama, "Perancangan Prediksi Untuk Menentukan Indeks Harga Saham Menggunakan Jaringan Syaraf Tiruan," KINETIK, pp. 125-130, 2017.

[4] A. Novita, "Prediksi Pergerakan Harga Saham Pada Bank Terbesa rDi Indonesia Dengan Metode Backpropagation Neural Network," JUTISI, pp. 965-972, 2016.

[5] Kompasiana, "Apa Itu Saham?," 18 Januari 2017. [Online]. Available:

https://www.kompasiana.com/kelasinvesta si/587f2786f77e61c0132809a8/apa-itusaham?page $=$ all. [Accessed 9 Oktober 2020].

[6] A. A. G. A. Krisna and N. G. P. Wirawati, "PENGARUH INFLASI, NILAI TUKAR RUPIAH,SUKU BUNGA SBI PADAINDEKS HARGA SAHAM GABUNGAN DI BEI," E-Jurnal Akuntansi Universitas Udayana 3.2, pp. 421-435, 2013. 
[7] Accurate, "Trading Adalah: Pengertian, Jenis, Keuntungan dan Kerugiannya," 15 Juni 2021. [Online]. Available: https://accurate.id/ekonomikeuangan/trading-adalah/.

[8] Solikhun, M.Saffi and A. Trisno, "JARINGAN SARAF TIRUAN UNTUK MEMPREDIKSI TINGKAT PEMAHAMAN SISIWA TERHADAP MATAPELAJARAN DENGAN MENGGUNAKAN ALGORITMA BACKPROPAGATION," Jurnal Sains Komputer \& Informatika (J-SAKTI), pp. 24-25, 2017.

[9] A. Tuovila, "Forecasting," 24 September 2020. [Online]. Available:

https://www.investopedia.com/terms/f/fore casting.asp. [Accessed 27 April 2021].

[10] I. R. Saretta, "Berencana Terjun ke Dunia Saham? Kenali Dulu IPO Beserta Kaitannya dengan Investor," 15 April 2020. [Online]. Available:

https://www.cermati.com/artikel/berencana -terjun-ke-dunia-saham-kenali-dulu-ipobeserta-kaitannya-dengan-investor. 